\title{
Finance and Institutional Investors
}

\section{Citation}

Jung, Jiwook, and Frank Dobbin. 2012. Finance and institutional investors. In The Oxford handbook of the sociology of finance, ed. Karin Knorr Cetina and Alex Preda, 52-74. New York: Oxford University Press.

\section{Published Version}

doi:10.1093/oxfordhb/9780199590162.013.0004

\section{Permanent link}

http://nrs.harvard.edu/urn-3:HUL.InstRepos:32116902

\section{Terms of Use}

This article was downloaded from Harvard University's DASH repository, and is made available under the terms and conditions applicable to Other Posted Material, as set forth at http:// nrs.harvard.edu/urn-3:HUL.InstRepos:dash.current.terms-of-use\#LAA

\section{Share Your Story}

The Harvard community has made this article openly available.

Please share how this access benefits you. Submit a story.

Accessibility 


\title{
THE \\ SOCIOLOGY \\ OF FINANCE
}

\author{
Edited by \\ KARIN KNORR CETINA \\ and \\ ALEX PREDA
}


CHAPTER 3

FINANCE AND INSTITUTIONAL INVESTORS

JIWOOK JUNG AND FRANK DOBBIN

\section{INTRODUCTION}

Institutional investors have come to play a central role in financial markets since the early 1970s. They controlled about three out of ten shares of Fortune 500 companies in 1970. Today they control seven out of ten. 'The aging of the baby boom generation, coupled with new fiduciary requirements for defined benefit pension plans, contributed to this change. As the retirement savings of the baby boom generation piled up, the regulatory changes led employers to favor individual retirement accounts managed by Fidelity, Vanguard, and the like. In the process American workers and pensioners came to own the lion's share of stock in most large companies, with institutional investors representing their interests.

Some who anticipated the democratization of corporate ownership through pension investments, in the United States and elsewhere, described a gradual road to socialism (Stephens 1979). From the 1980s, stakeholder theory gained ground by suggesting that the firm was beholden not only to shareholders, but to other stakeholder groups, from customers to employees to the community (Donaldson and Preston 1995; Freeman 1984). As ownership became more widespread, firms might have been expected to embrace stakeholder theory, for workers and pensioners were becoming majority shareholders. Instead, institutional investors and then corporate leaders embraced agency theory and the shareholder value approach. They rewrote the title of Milton Friedman's 1970 article, "The Social Responsibility of Business is to Increase Its Profits," replacing the last two words with "Share Value." Agency theory offered a litany of innovations designed to ensure that executives pursued the interests of shareholders, rather than feathering their own nests. The theory reduced the common interests of diverse shareholders to a single metric, share value. Institutional investors promoted the theory with a vengeance, encouraging firms through shareholder proposals and private bidding to put its prescriptions into place.
We review evidence showing that firms responded to the entreaties of institutional investors, putting most of the innovations they lobbied for into place. We also review evidence concerning the effects of these innovations. Most have not proven to improve share value, but quite a few have had adverse consequences for worker-owners who hold stock. Executive compensation through stock options has transferred wealth from worker-owners who hold stock to executives. Dediversification has been accomplished through corporate restructurings, typically accompanied by massive layoffs. Debt financing has made firms vulnerable when the economy slumps, and more likely to declare bankruptcy, close their doors, and bail out on their pension obligations. The mandate to increase share price through cost-cutting has led firms to downsize, eliminating jobs, and to curtail contributions to defined-benefit pension plans, leaving those plans underfunded and leaving workers or taxpayers to pay the price.

Institutional investors thus promoted a new model of management that has been good for the financial elite of executives, investment bankers, hedge fund managers, private equity chiefs, and institutional investors, but not so good for the workers and pensioners who are now the majority shareholders. The distribution of national income is one indicator of the consequences of these changes. By 2007, the richest 1 percent of Americans took home 23.5 percent of national income, up from 9 percent in 1970 (Piketty and Saez 2003, 2009). Take out the star athletes and Hollywood celebrities, who are not part of the financial elite, and the numbers change little.

We chart the role of institutional investors in promoting changes in corporate management under the banner of shareholder value, and review evidence that these changes did little to promote share value and that they resulted in several disadvantages for the American worker-owner. Some of the changes have been described as inevitable given growing global competition, but elites in other developed countries responded quite differently to the challenge of globalization. German firms, for instance, emphasized products that required high skill levels and could not readily be produced effectively elsewhere, avoiding massive layoffs, sustaining relatively high median wages, and forestalling the concentration of income (Thelen 2003).

\section{A word about evidence}

In addition to reviewing evidence from a number of studies, we present evidence from a representative sample of 783 major American firms to track the move toward agency theory prescriptions between 1980 and 2005. We also review evidence about the effects of different innovations adopted under the flag of shareholder value. We chose a representative group of industries from Fortune lists of industry leaders, selecting equal numbers of firms from aerospace, apparel, building materials, chemicals, communications, computers, electrical machinery, entertainment, food, health care, machinery, metals, oil, paper, pharmaceuticals, publishing, retail, textiles, transportation, transportation equipment, utilities, and wholesale. We sampled firms from Fortune lists in odd years between 1965 and 2005 so as to achieve a sample that represents both rising and declining 
firms. The core data come from Standard and Poor's Compustat data files. A number of variables, as noted, come from other sources.

\section{THE RISE OF INSTITUTIONAL INVESTORS}

The rise of both institutional investors and agency theory can be traced to the economic stagnation that began in the late 1960 s and continued through the 1970 s. Stagnation helped to convince Congress to expand the regulation of pensions in 1974, for company pension funds suffered under high inflation and low growth. The Pension Reform Act contributed to the popularity of individual retirement accounts among corporations by making defined-benefit pension plans more expensive to run, and this shifted pension contributions into the hands of mutual fund managers. Meanwhile, America was looking for a scapegoat for the economic malaise of the 1970s, and a way out of the economic quagmire. Agency theory came along toward the end of the decade to offer up the selfish corporate executive as the scapegoat, and to offer a tidy set of prescriptions for reorienting the firm to making money.

Newly influential institutional investors, who now controlled much of the money that flowed into capital markets, became enamored of agency theory and pushed firms to follow its dictates about executive compensation, industrial focus, debt financing, and costcutting to improve profits and share value. Agency theory had conjoined the interests of institutional investors and corporate executives, for under the new compensation schemes based on stock options, executives saw windfalls each year in which share prices grew, but shared none of the downside risk with investors. The bonuses of the institutional fund managers were likewise tied to growth in share value, and, like executives, fund managers did not share in the downside risk. By promoting stock options, in particular, institutional investors ensured that the interests of corporate executives would coincide with their own interests, if not always with those of shareholders, who held most of the downside risk.

\section{The Pension Reform Act of 1974 and the growth of mutual funds}

The expanding power of institutional investors in equity markets was in large measure an unintended consequence of Washington's efforts to insure the private pension system that had arisen alongside the public system during the twentieth century (Dobbin 1992). Benefits from private pensions combined with government-sponsored Social Security provided comfortable retirement incomes for employees in high-paying, unionized sectors. The passage of the Employee Retirement Income Security Act of 1974 marked the high point of this uniquely American system. Designed to guarantee that plans were fully funded and could pay projected expenses, the act unintentionally led to the growth of defined contribution pension plans, such as the $401(\mathrm{k})$ (Hacker 2006). The new

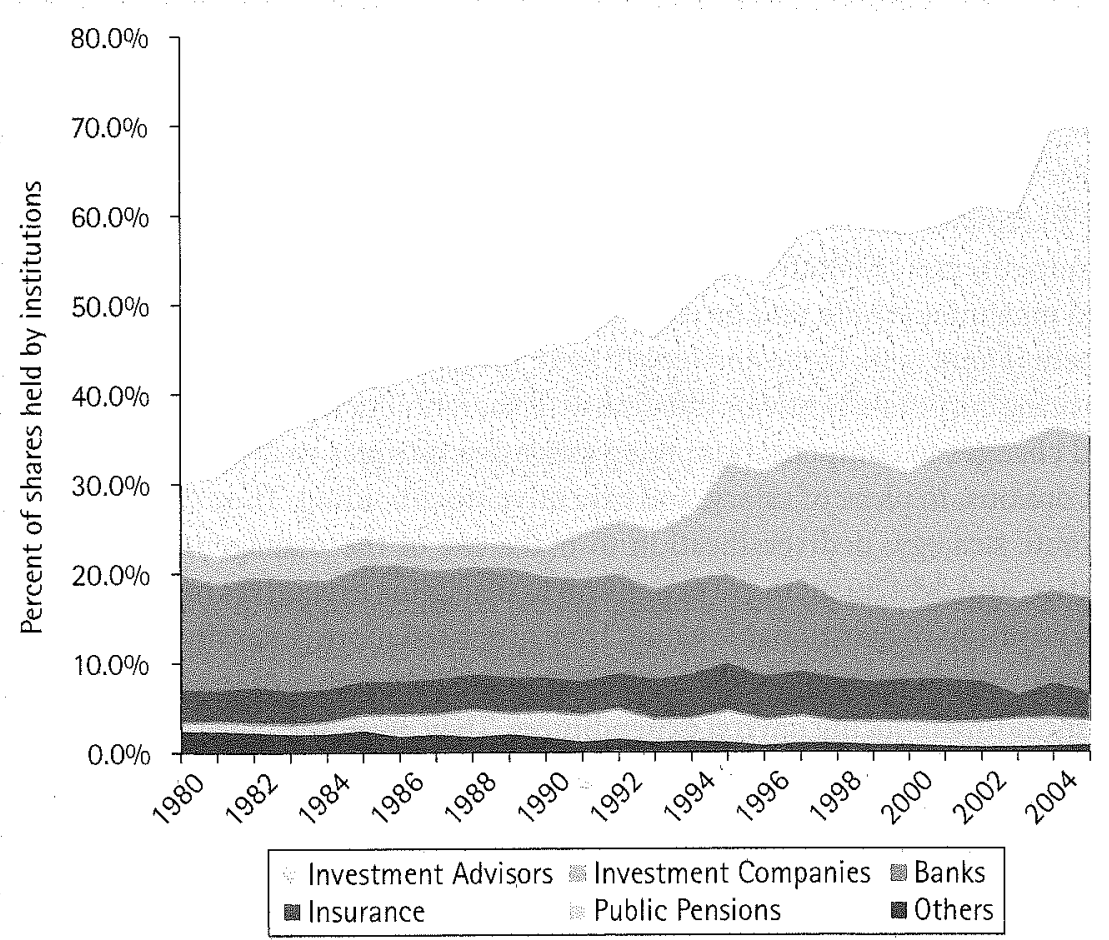

FIGURE 3.1 Institutional Investor Holdings in Large US Firms

Source: Authors' sample of 783 large US corporations.

regulations increased the cost of defined benefit plans, and in the context of low growth defined contribution plans now seemed a better bet for firms hoping to transfer the risk of poor investment returns to the individual. The shift to defined contribution plans was rapid. In 1981, about 60 percent of workers with private pensions depended exclusively on a defined benefit plan, but in 2003 , this was down to only 10 percent. Meanwhile the percentage of workers who depended exclusively on a defined contribution plan increased from 20 to 60 percent (Buessing and Soto 2006).

In Figure 3.1 we show the growth in holdings by institutional investors between 1980 and 2005 , based on the 783 leading American firms in our sample. In 1980, institutional investors controlled three of ten shares in the average company. Banks held the biggest proportion of shares, followed by investment advisors (such as Goldman Sachs) and insurance companies. By 2005 , bank holdings had declined as a proportion of all shareholding, and investment advisors and investment companies (such as Fidelity) held the largest aggregate positions in the stock market. Overall, institutional investors controlled 70 percent of shares in the average company by 2005 , with investment advisors and investment companies, which manage retirement and personal accounts, controlling half of shares in the typical firm. 


\section{The rise of agency theory}

The stagflation of the 1970 s stimulated business to search for a diagnosis and remedy. Agency theorists offered both. Jensen and Meckling's (1976) seminal article suggested Agency theorists of sync. Executives acted to serve their own interests, building large diversified firms to sync. Exective risk of failure and to raise their own salaries, rather than focused firms that would maximize profits, and turning away from efforts by boards and investors to monitor them (Fama 1980; Fama and Jensen 1983, 1985; Jensen and Meckling 1976).

To bring corporate behavior into line with shareholder interests, agency theorists prolo stock options, in place of salary, and executive stockholding. They proposed changes to stock options manement team's industry corpertise and debt financing of expansion to discipline executives inclined to use profits for acquisitions of questionable value. They proposed more generally that firms cut costs to increase profit margins, and executives pursued a number of strategies for doing jus that, including reducing payroll expenditures. They proposed governance and monitor ing reforms as well that we do not take up here, including more independent boards and more transparency to facilitate external monitoring by securities analysts (Jensen and Meckling 1976). Michael Jensen popularized these ideas, publishing in the business press as well as in academic journals (Jensen 1984, 1989). Below, we show that leading firms embraced most of these prescriptions. But first we review the role of fund manag ers in popularizing the innovations.

\section{Institutional investor support for agency theory prescriptions}

Institutional investors took the lead in promoting agency theory precepts, though hostile takeover firms and securities analysts also played roles, as we discuss below. Executives were generally wary of the changes, preferring the stability of the management system they had developed to a system designed to make their firms more entrepreneurial, and to increase risk. Hence, someone had to hold their feet to the fire. Among institutional investors, public pension funds led the charge, sponsoring an array of shareholder proposals to improve board governance, expand external monitoring, and compensate executives for raising share price (Carleton et al. 1998; Davis and Stout 1992; Gourevitch and Shinn 2005; Jacoby 2007; Proffitt 2001; Useem 1996). CalPERS (California Public Employees' Retirement System) became active in the early 1980 s (Blair 1995; Schwab and Thomas 1998), sponsoring shareholder resolutions and, in 1995, spearheading the Council of Institutional Investors (CII), which assembled public, private, and union fund managers. CII's "shareholder bill of rights" called for greater shareholder input to reduce agency costs (Jacoby 2007).

Mutual fund managers often worked behind the scenes to promote innovations, in part because they hesitated to challenge firms to whom they marketed pension instruments
(Davis and Kim 2007; Gourevitch and Shinn 2005). Moreover, as institutional shareholding grew after the 1970s, managers at the largest funds were more and more likely to hold large stakes in a given firm, and thus more inclined to try to influence management rather than simply pull their investments out. Although some institutional investors today still take the "Wall Street Walk" when dissatisfied with management, that is, sell stock (Parrino et al. 2003), that strategy is difficult for investors who hold large blocks to carry out, for they risk a substantial price discount in order to liquidate (Coffee 1991).

\section{CONSEQUENCES OF SHAREHOLDER-VALUE PRESCRIPTIONS}

The shareholder value movement, fueled by the growth of institutional shareholding, found its voice in a budding financial theory in economics-agency theory. According to the theory, in the 1950 s and 1960 s America's leading companies were run by, and for, managers. Jensen and Meckling (1976) proposed that the managers of firms should rightly be working for shareholders. Agency theory moved quickly beyond the ivory tower in the context of the economic crisis of the 1970s. The popular business press provided advice about how to implement agency theory prescriptions in pursuit of the interests of shareholders (Baker and Smith 1998; Hammer and Champy 1993; Prahalad and Hamel 1990; Walther 1997). We discuss several of the key prescriptions offered by agency theorists, as well as innovations promoted by business leaders under the broad heading of shareholder value. We explore the uptake of the new pay-for-performance compensation scheme, the dediversification strategy, the debt-financing strategy, and cost-cutting through downsizing and limiting pension contributions. In the process we review evidence about the effects of these innovations, both on firm performance and on workers.

\section{Equity-based compensation for executives}

Agency theorists argued that managers tend to be more risk-averse than shareholders would like them to be (Eisenhardt 1989). CEOs fortify their empires against collapse when they should be making money for shareholders. This represents an important cost of agency, or of having a hired hand run the firm you own. One way of reducing agency costs is to have managers hold equity (Jensen and Meckling 1976; Jensen and Murphy 1990). If they hold 100 percent of equity, agency costs drop to zero. Agency theorists called for CEOs to hold substantial equity and to be paid for performance through stock options and bonuses. Previously, they argued, firms made the mistake of paying their executives like bureaucrats, tying compensation to showing up for work rather than to performing (Jensen and Murphy 1990).

The old executive salary system encouraged expansion rather than profits, because the highest salaries typically went to the managers of the largest corporations. Stock 
options would remedy this by entitling executives to buy a set number of shares at a future date, typically three years hence, but at the market price of the stock on the date of in or the from increases in stock price between the date of pricing and the date of vesting.

Institutional investors became vocal advocates for the new equity-based executive compensation system (Gourevitch and Shinn 2005; Proffitt 2001; Useem 1996). Investors bid un the price of firms that announced long-term incentive plans that would increase bid up the price (he executive equity (Westphal and Zajac 1998). CEO 2003). Options led to particularly close value of initial public offerings (Dalton et al. 2003). Op alignment of executive and fund manager interests, as noted, because executives and fund managers alike were rewarded when stock price rose, but were not punished when it fell.

Stock options spread far and wide, contributing to a sharp increase in executive comPe pensation. Hedian CEO compensation rose seven-fold from 1984 to American firms, by form. Median CEO compensation rose seck option grants and 2004 , to over $\$ 3,500,000$. Much of the rise came in the form of stock option grants and bonuses.

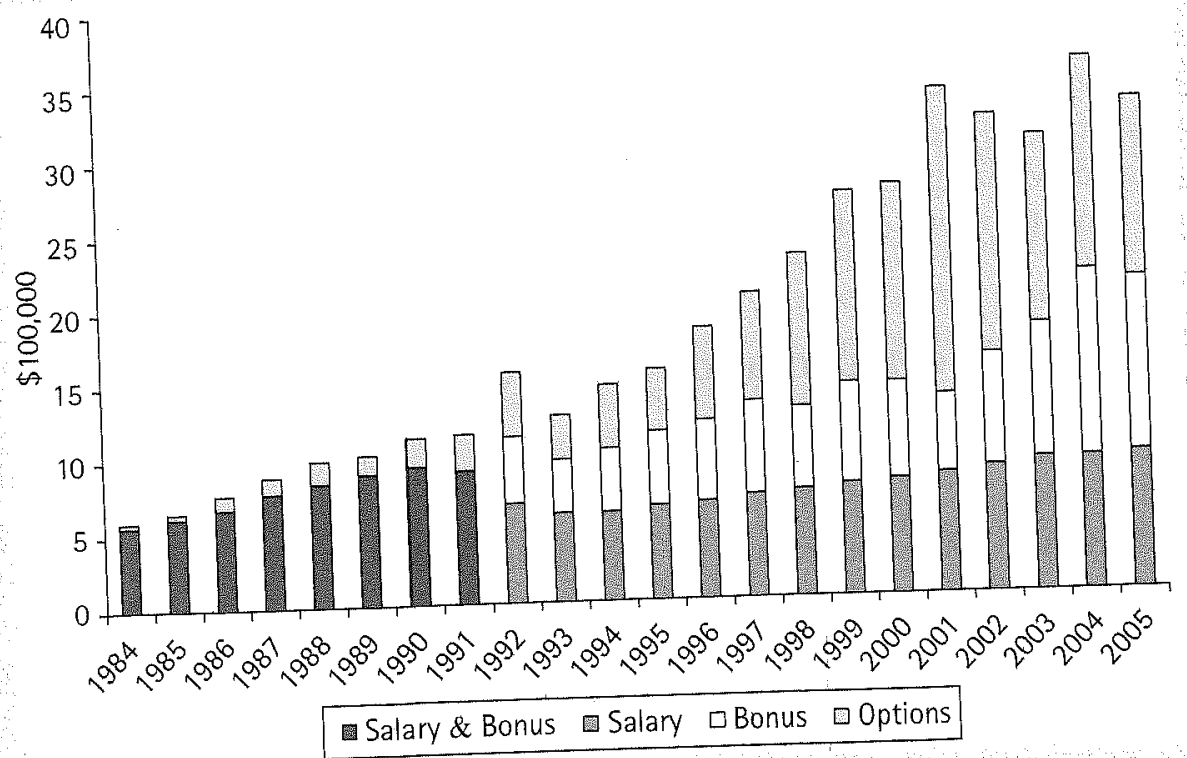

FIGURE 3.2 The Changing Form of CEO Compensation

Source: Author' sample of 783 large US corporations. Salary and bonus are not reported separately until 1992 Source: Authors' sample of 783 large Us corpla (of larger firms) for that one year. Data on CEO compensation The spike in 1992 results from a smallerid Yermack. CEO compensation data after 1992 are from Standard and from 1984 to 1991 were provided by David Yermack. CEO's ExecuComp database, available through Compustat.
Poor's

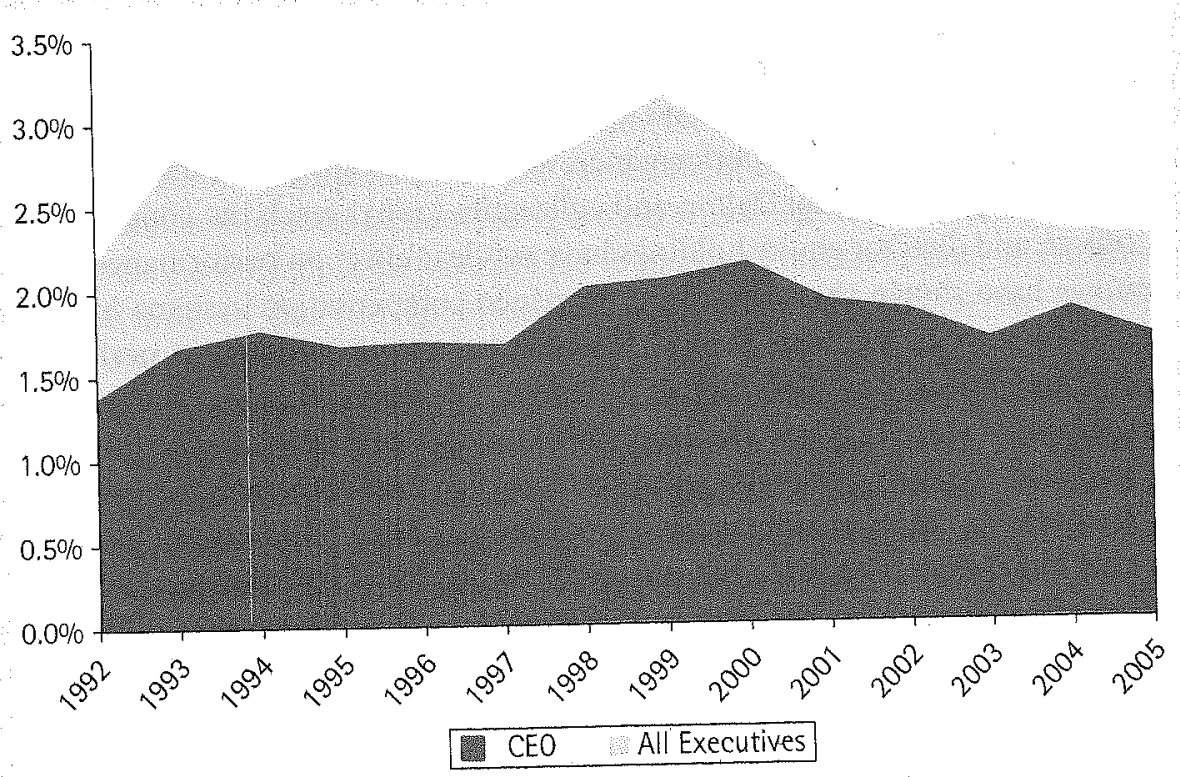

FIGURE 3.3 Equity Holding Among Executives

Source: Authors's sample of 783 large US corporations. Unexercised options excluded. Data on executive equity holding are from the ExecuComp database

Firms did not heed the advice to require executives to hold equity, however. Over time, despite the fact that executives had significantly more wealth to invest thanks to stock options, they did not invest it in the firms they ran. Figure 3.3 shows equity ownership by executives in our sample of 783 firms between 1992 and 2005 , excluding unexercised options. Data on earlier years are not available. Equity ownership by $\mathrm{CEO}$, and by all executives, scarcely changes over the period while, as we see in Figure 3.2, median income tripled.

What were the effects of stock options? First, they do not appear to have increased corporate profits or share value, although they do appear to have increased executive risk-taking, leading more often to outsized losses than to outsized gains. Second, they do appear to have encouraged executive earnings "management" to increase share price, that is, accounting fraud of the sort responsible for the Enron debacle. Third, the most dramatic effect of stock options was to transfer wealth from shareholders to the financial elite. Corporate income that might have gone to workers within the firm, in the form of increased wages, or to worker-owners in and out of the firm in the form of dividends, went instead to top executives.

\section{Profits and risk-taking}

Agency theory suggests that stock options and equity holding should lead to improved profits and share price. In line with the theory, one study suggests that the spread of 
stock options caused total compensation to be much more closely aligned with firm performance (Hall and Liebman 1998). Evidence that option grants and equity holding lead firms to superior performance, however, is weak and there is some evidence that options increase recklessness. Many studies have looked for a relationship between stock options or equity holding and corporate performance, without finding one. In a meta-analysis of 220 studies of equity holding, Dalton and colleagues (2003) reach the conclusion that $\mathrm{CEO}$, officer, and director equity holdings have no clear effect on performance. Quite a few studies have shown that pay-for-performance compensation systems have been subverted by executives, who benefit whether or not they improve performance (Bebchuk and Fried 2003; Bebchuk et al. 2002). Moreover, Sanders and Hambrick (2007) show that stock options encouraged reckless risk-taking by executives, because options reward executives for increases in stock price in the near term but do not punish them for declines. Their analysis shows that option-loaded CEOs are more likely to deliver big losses than big gains. One reason for the excessive risk-taking, they suggest, is that boards did not follow the agency theory dictum of requiring executives to hold more equity.

\section{Earnings management}

Stock options create an incentive for executives to ensure that earnings meet analyst projections. As investors became dependent on securities analysts to evaluate firms, they paid increasing attention to projections. When earnings fall short of projections, stock price usually dips, which is bad news for executives holding options. Earnings management, by which firms manipulate reported earnings to please analysts, was one response. One signal of earnings management is earnings restatement, by which firms report corrected figures after they have submitted erroneous figures. Restatements rose among Fortune 500 companies over time, and some studies link the rise to stock option grants (Burns and Kedia 2006; Efendi et al. 2007). Using data on thousands of quarterly reports between 1974 and 1996, Degeorge et al. (1999) show that firms are significantly more likely to report earnings that exactly match analyst predictions than they are to report earnings that overshoot or undershoot by even a penny, suggesting that firms regularly manage earnings to hit analyst targets. Some of the accounting techniques they use amount to little more than fraud, and were prominent in the Enron, WorldCom, and Tyco scandals. By misleading investors about profits, executives at those firms fattened their own wallets before the share price collapsed, wiping out the investments of workerowners. Thus, for instance, over half of the funds in Enron's employee $401(\mathrm{k})$ plans were invested in Enron shares when the company's stock price dropped from $\$ 90$ dollars to 26 cents in November of 2001 . More generally, earnings management often catches up with firms, and so while executives may benefit from boosting share value before cashing in on stock options, the average shareholder eventually pays the price.

\section{Transfer of profits to executives}

Finally, stock options have transferred the wages of the firm away from its employees and investors. Agency theorists promote stock options with the idea that option grants come at no cost to the firm, because they simply reward executives with a portion of the earnings they have achieved for the firm. But evidence that stock option grants do not promote corporate profits or share value belies that idea. If stock options do not lead to increases in firm value, then options do not pay for themselves. Investors pay for them through diluted ownership, and workers pay for them through diluted wages. The cost of options and bonuses can be seen in Figure 3.2, which shows the dramatic increase in $\mathrm{CEO}$ income. As stock options have not led to increases in share value, one might conclude that most of the run-up in compensation came directly at the expense of shareholders.

What were the effects on workers of the growing share of income accruing to the chief executive? Between 1945 and 1970, working Americans enjoyed steady growth in earnings and the gap between rich and poor remained stable. By the early 1980s, median earnings were stagnating and income inequality was growing (Morris and Western 1999). By the early 1990s, a significant number of workers were earning less than their 1960 s counterparts (Bernstein and Mishel 1997). The financial crisis of 2008 exacerbated these trends, and the earnings gap is now at its widest since the census began keeping track and is the widest of any Western industrialized nation (DeNavas-Walt et al. 2010). As we noted at the outset, the top 1 percent of Americans earned 23.5 percent of national income in 2007, up from 9 percent in 1970 (Piketty and Saez 2003, 2009).

Change in the distribution of corporate income among our 783 large US firms can be seen in Figure 3.4, charting chief executive compensation over the average income of all

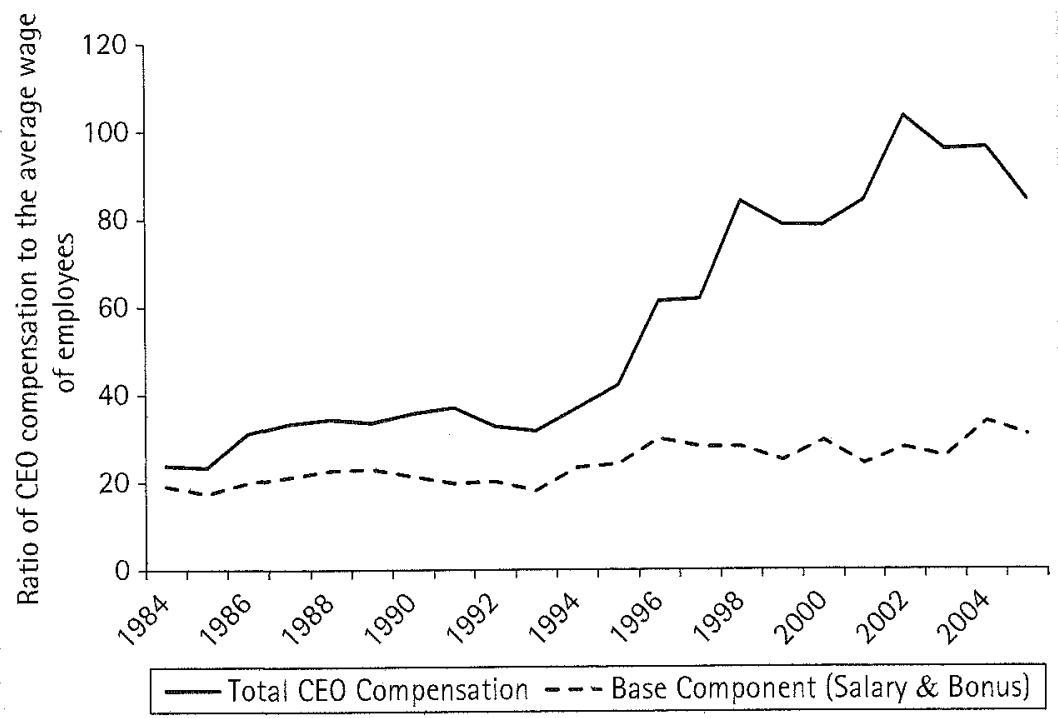

FIGURE 3.4 Ratio of the CEO Compensation to the Average Compensation for Other Employees Source: Authors' sample of 783 large US corporations. 
other employees. Ideally we would remove top management team (TMT) compensation from the denominator, but full data on TMT compensation are not available. We estimate the average compensation for all employees but the CEO, dividing labor expense by the total number of employees (minus CEO compensation). The ratio of CEO com pensation to average compensation increases dramatically, particularly after the mid1990 s. Most of the change is caused by stock options grants; the ratio of base pay (salary and bonus) barely increased.

\section{Industrial focus}

From the 1950s through the 1970s, leading American firms remade themselves as conglomerates. By 1980, almost half of the Fortune 500 operated in three or more two-digit glomerates. By 1980, almost half of the Fortune 500 shile only 25 percent operated in a single industry (Davis et al. 1994: 553). Agency theory challenged the efficiency of conglomerates. Portfolio theory had provided a rationale for conglomeration, suggesting that the modern firm should run an internal capital market, investing in promising sectors and spreading risk across different sorts of industries. Agency theory suggested, in the midst of the stagflation of the 1970s, that diversification was not in the interest of shareholders, actuiring businesses of questionable value that and managers alone stood to gain by acquiring businesses of questionable value that would reduce the risk of corporate collapse (Jensen and Meckling 1976). They insisted
that the investor, not the firm, should assemble portfolios to spread risk, and a diversified investor should expect some firms to be culled from the herd (Amihud and Lev 1981; Bettis 1983; Teece 1982). Shareholders should shy away from ponderous conglomerates that held poorly performing enterprises in industries little understood by their executives (Shleifer and Vishny 1989, 1997).

Firms should be lean and focused. This idea was widely promoted by management consultants in the wake of agency theory. The first blockbuster management bible, In Search of Excellence (Peters and Waterman 1982), admonished executives to "stick to the knitting, by focusing on the core business of the firm. In 1990 the reengineering gurus C. K. Pralahad and Gary Hamel published "The Core Competencies of the Firm" in Harvard Business Review, arguing that a management team should play on its strengths. As Michael Useem (1996: 153) argues, "While diversification had been a hallmark of good management during the 1960 , shedding unrelated business had become the measure during the 1980 s and 1990s."

Many institutional investors came to favor focused firms not only because they were converts to agency theory, but also because they preferred to build their own diversified portfolios out of firms with clear industry profiles (Dobbin and Zorn 2005). Hostile takeover firms encouraged dediversification in the 1980s, targeting diversified conglomerates that they could break into pieces to be resold at a profit (Davis et al. 1994; Fligstein and Markowitz 1993; Liebeskind et al. 1996; Matsusaka 1993). Institutional investors were deeply involved in hostile takeovers in the 1980 s, often supporting takeovers that were opposed by incumbent management (Holmstrom and Kaplan 2001). Where

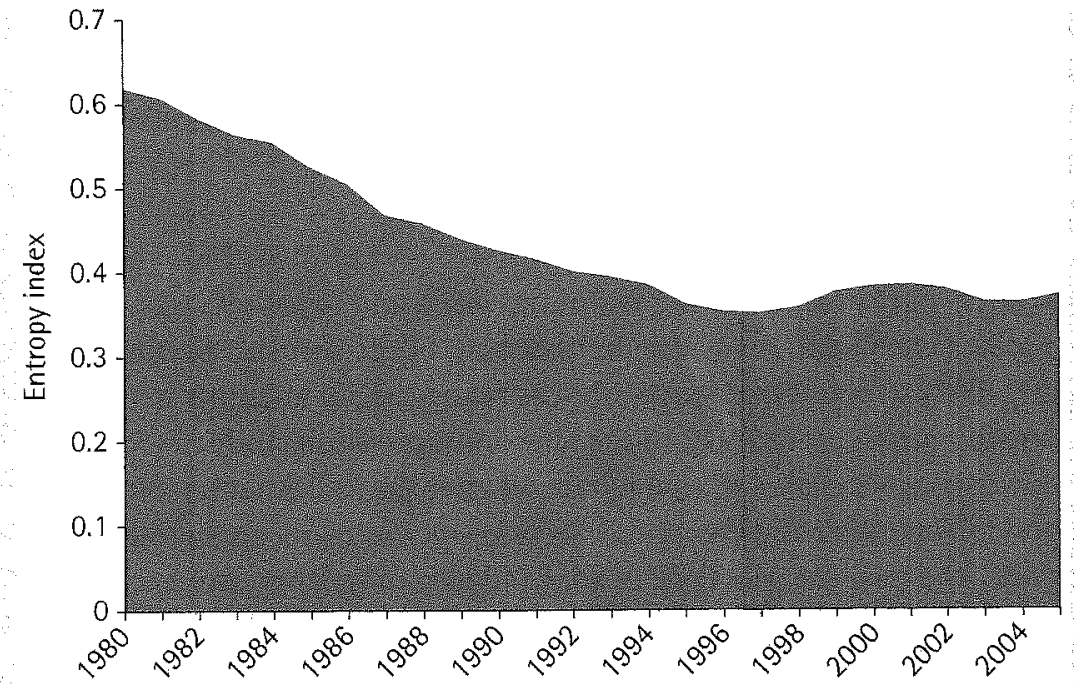

FIGURE 3.5 Average Level of Diversification

institutional investors held sway, firms were fast to dediversify. From the 1980 s, Fortune 500 companies with concentrated ownership were most likely to spin off unrelated businesses (Useem 1996: 153). The threat of hostile takeovers induced many conglomerates to dediversify on their own. Securities analysts joined the dediversification chorus. They also carried the banner of agency theory, but had their own reasons as well. Analysts specialized by industry, and conglomerates that did not fall into a neat category usually failed to win coverage. Executives coveted coverage because coverage was overwhelmingly positive, encouraging investors to buy their stock. This motivated companies to dediversify in order to win coverage and boost institutional investor interest (Zuckerman 1999, 2000).

Fund manager preferences clearly influenced firms (Campa and Kedia 2002). In Figure 3.5, we chart the level of diversification among our sample of large American firms, using the entropy index, which measures diversification based on the contribution of each industry to the firm's sales. Diversification declined considerably between 1980 and the mid-199os. This pattern suggests that even after the hostile takeover wave subsided, diversification continued to decline, as executives voluntarily spun off units unrelated to their core businesses.

\section{Dediversification and performance}

Did dediversification improve performance? The evidence is mixed. Some studies find a "conglomeration discount" in stock price in the 1960 s and after the mid-197os, but not in between (Matsusaka 1993; Servaes 1996), and others find no discount at all (Campa and 
Kedia 2002; Villalonga 2004). The pattern is consistent with the proposition that the post-1975 conglomerate stock price discount was a consequence of investors fulfilling the prophesy of agency theory (LeBaron and Speidell 1987; Wernerfelt and Montgomery 988). While it is not clear that focused firms have higher profits, it does seem clear that corporate spinoffs produced widespread layoffs.

\section{Dediversification and job losses}

One clear effect of the restructuring fad of the 1980 and 1990 s was that many workers lost their jobs. Consolidations within an industry, of the sort that became popular, are particularly likely to result in downsizings, as management attempts to make the combined company profitable quickly. In the telecommunications industry, the list of postprof merger downsizings includes 10,000 job losses after the Bell Atlantic-Nynex m,000 jobs lost after SBC's acquisition of AT\&T in 2005 (Cauley 1997; Romero 2000; Young 2005) In defense, Martin Marietta announced 11,000 jobs cut after acquiring GE Aerospace in 1993, and two years later, when Martin Marietta merged with Lockheed, it cut a further 12,000 jobs (Gilpin 1995; Sims 1993). Restructuring to produce corporate focus meant significant job losses across a range of industries.

Hostile takeovers of the 1980 s generally had negative consequences for employmen (19) Brison and Bluestone 1988, and groups of individual investors, borrowed conily to acquire targets, and then, to pay off debts, they sold assets and cut wage costs. Some argued that anticipated labor cost savings explained the high takeover premiums (Shleifer and Summers 1988). Few empirical studies have assessed that laim, but Bhagat et al. (1990), examining 62 hostile takeover contests between 1984 and 86 , premium. 1986 , reported that layoffs could account for sider job cuts in the bidding firm.

The hostile takeover wave receded after the crash of the junk bond market in the late 88 , but the level of merger and acquisition (M\&A) activity reached another peak in the 1990 s, as industrial giants combined in hope of enhancing industrial focus and market power.

\section{Debt-financing}

A third way of reducing agency costs, according to Jensen and Meckling (1976), is to take on debt. Debt reduces the share of equity financing and thus moderates the conflict of interest between shareholders and managers. Agency costs stem from executives preference for stability, which can lead them to make investments that will reduce the risk of firm failure but also dilute profits. Investors with diversified portfolios should prefer high-reward strategies that carry some risk of firm failure, whereas executives should prefer strategies that minimize failure risk. According to the theory, CEOs will not borrow money at 6 percent for an endeavor that will return 4 percent, because they

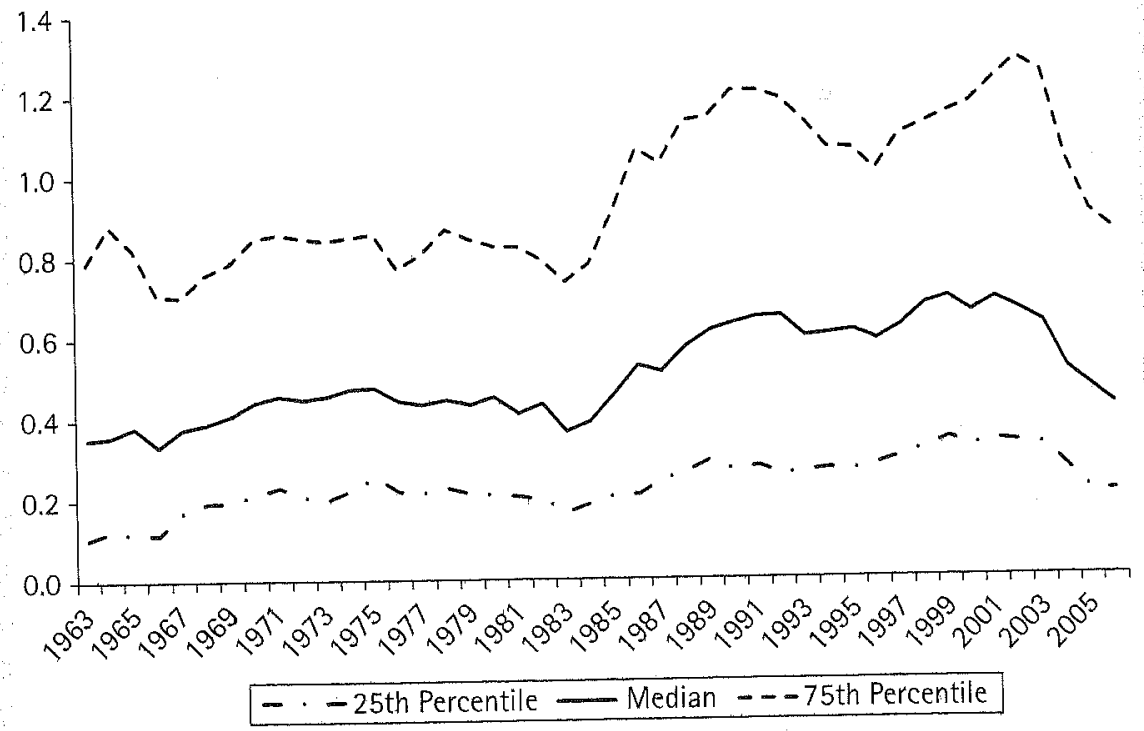

FIGURE 3.6 Debt-to-Equity Ratio

Source: Authors' sample of 783 large US corporations. Debt-to-equity ratio is calculated as total long-term debt divided by common equity. Data on both items are from Compustat.

must account for capital costs, but they might invest profits, because they do not have to account for capital costs.

Under the theory, institutional investors came to favor firms that used debt financing, taking it as a signal of management's conviction that new investments will pay off. Because debt financing multiplies returns to equity, agency theory suggests that shareholders should prefer it to the issuance of new stock, and that they should prefer to see profits returned to shareholders through dividends or share buybacks that boost share value (Westphal and Zajac 1998; Zajac and Westphal 2004). The stock market thus reacts positively to most leverage-increasing transactions, such as debt-for-equity swaps (Finnerty 1985; Lys and Sivaramakrishnan 1988).

Following the advice of agency theorists, large American corporations increased leverage significantly after 1980 . In Figure 3.6 , we report debt-equity ratios by quartiles for the firms in our sample from 1963 to 2005 . Before the mid-1980s, the median firm had about 40 cents of debt for every dollar of equity. This rose to about 60 cents after the mid-1980s. For firms at the 75 th percentile, debt rose from about 80 cents on the dollar to over 110 cents for much of the last half of the period.

\section{Debt and corporate vulnerability}

While debt financing may reduce agency costs associated with free cash flow (Jensen 1986), it can increase corporate vulnerability (Modigliani and Merton 1958). Recent 
studies show that firms with heavy debt burdens are especially vulnerable during economic downturns (Campello 2003; 2006). Heavy use of debt can also be problematic on a new investment do during economic upturns when interest rates rise; if returns from ay find itself with debt it not exceed the interest on the bonds used to finance r a frequently made bets on high-risk cannot pay off. In the circumstance, executives have frequents do not pay off (Crutchley investments to pay bondholders when their initial investments do not pay (Crs and Hansen 1989: 37). Many accounts of the recent financial crisis point to excess leverage by mortgage lenders, which put them at risk when mortgage-backed securities and mortgages themselves failed, and encouraged them to try even riskier moves to save themselves (Johnson 2008; Posner 2009; Sorkin 2009). Hence, debt can make a firm the vulnerable both in periods of economic an an investors alike pay the cost of this vul-

ods of recession, when sales lag. Employees and investors alis

\section{Defunding pension funds}

Corporations that took on excessive debt, whether as part of a takeover process or as part of a business strategy, increasingly withdrew investments from pension funds. Ippolito and James (1992) show that there is a strong and statistically significant increase in pension terminations following leveraged buyout announcements, and other studies (I9) Mittelstaedt 1989; Stone 1987) find that firms with large debt burdens, which may have trouble raising cash in hard times, are more likely to raid well-funded pension plans. Bankruptcy judges often allowed firms to reduce assets in pension schemes that appeared to be overfunded. Following subsequent market

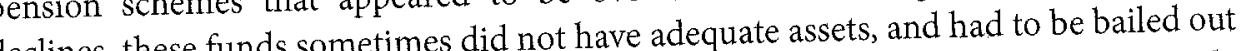
declines, these funds sometimes did cotharation. Employees and taxpayers ultimately by the Pension Benefit Guaran

\section{Raising value by downsizing}

Practitioners pursued agency theory's charge, of putting shareholder value first, with several strategies designed to reduce costs to raise profits and share price. A number of CEOs won fame through aggressive cost-cutting (Khurana 2002). "Chainsaw" Al Dunlap made his name at Sunbeam, and preached the virtues of restructuring and hareholder value in his bestselling autobiography, Mean Business: How I Save Bad Companies and Make Good Companies Great. Soon after arriving at Sunbeam in 1996, he Corkforce of 12,000 by half, an unheard of feat (Collins an 1996). The stock market welcomed the announcement, bus, in March of 1998, the board from $\$ 52$ to $\$ 26$ in 1997 as sales faltered. Nevertheless, in March extended another three-year contract that doubled Dunlap's salary and granted him staggering 3.75 million stock options. He responded with yet another plan to cut about 6,400 jobs, or 40 percent of total employment of the company after its acquisition of Coleman (Canedy 1998a)
Waves of downsizing swept through corporate America from the early 1980s, eroding what Paul Osterman (1999: 21) terms the "postwar institutional structure" of the labor market. Firms had laid off employees in hard economic times before, but now even healthy firms were laying off employees in the hope of boosting stock price (Cappelli 1999; Osterman 1999). Keeping investors happy was the motive. When Jonathan Schwartz, the new CEO of Sun Microsystems, announced on May 31, 2006, that the company planned to cut 4,000 to 5,000 jobs, he argued that the expected cost savings from the job cuts would help Sun meet analyst forecasts of a loss of two cents a share in the fourth quarter. Eastman Kodak announced a plan to trim 10,000 jobs despite strong profits, as it was under pressure from institutional investors to increase margins (Holusha 1993a). Xerox announced a plan to cut 10,000 jobs as well, or 10 percent of its workforce, despite consistent profitability; its CEO explained, "To compete effectively, we must have a lean and flexible organization which can deliver the most cost-effective document-processing products and services" (Holusha 1993b). Both the CEO and the institutional investor could agree on the goal of boosting share value (Flynn 2006). As firms strove to improve their stock performance under the oversight of demanding investors, they became more likely to downsize (Budros 1997; Lazonick and O'Sullivan 2000).

Downsizings thus increased over time, even when the economy was booming. In Figure 3.7, we plot the proportion of firms in our sample that announced at least one downsizing each year. Even though companies still cut jobs frequently during economic downturns (during the recessions in the early 1980s, the early 1990s, and the early

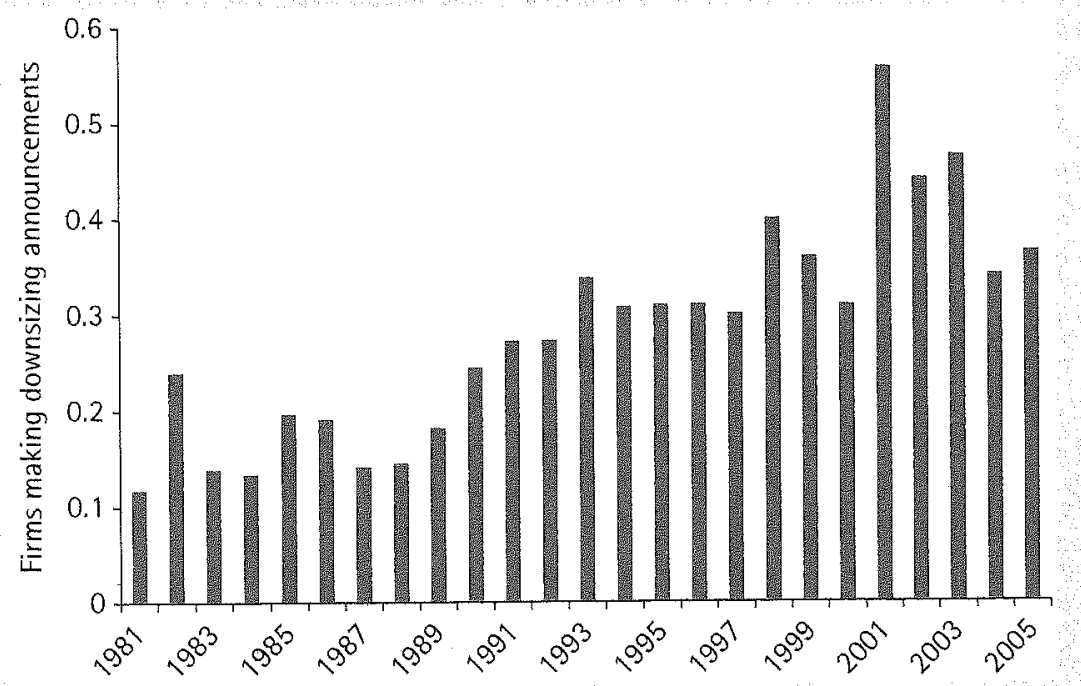

FIGURE 3.7 Proportion of Firms Making Downsizing Announcements Source: Authors' sample of 783 large US corporations. 
2000s), they continued to downsize throughout the 1990 s despite an improving economy.

\section{Raising value by cutting pension contributions}

The defined-benefit pension plan became a significant source of cost-cutting in the 1990s. Firms had generally moved away from those plans to reduce their costs. Even healthy firms, such as IBM and Sears, froze their defined benefit plans, moving employees over to defined contribution plans (Munnell et al. 2006). Between 2004 and 2006 more than 400,000 current employees and more than a million new workers were ffected by the freezes (Munnell et al. 2006). This transition itself transferred risk from firms to employees, as the new plans carried no guarantees against stagnation or loss (Hacker 2006).

In the 1990s, the run-up of the stock market made many defined-benefit plans appear to be overfunded, which enabled corporations to curtail or cease contributions. The 列 and rop in interest rates, this trend came to an end (Munnell and Soto 2007), but marand drop in interest rates, this trend came significantly underfunded and many employers have ket volatility he chart the average net funding status of neglected to fill the coffers. In Firms, calculated as the difference defined benefit plans in our sample of 783 large US firms, calculated as the difference between current pension assets and projected benefit obligations. Throughout the

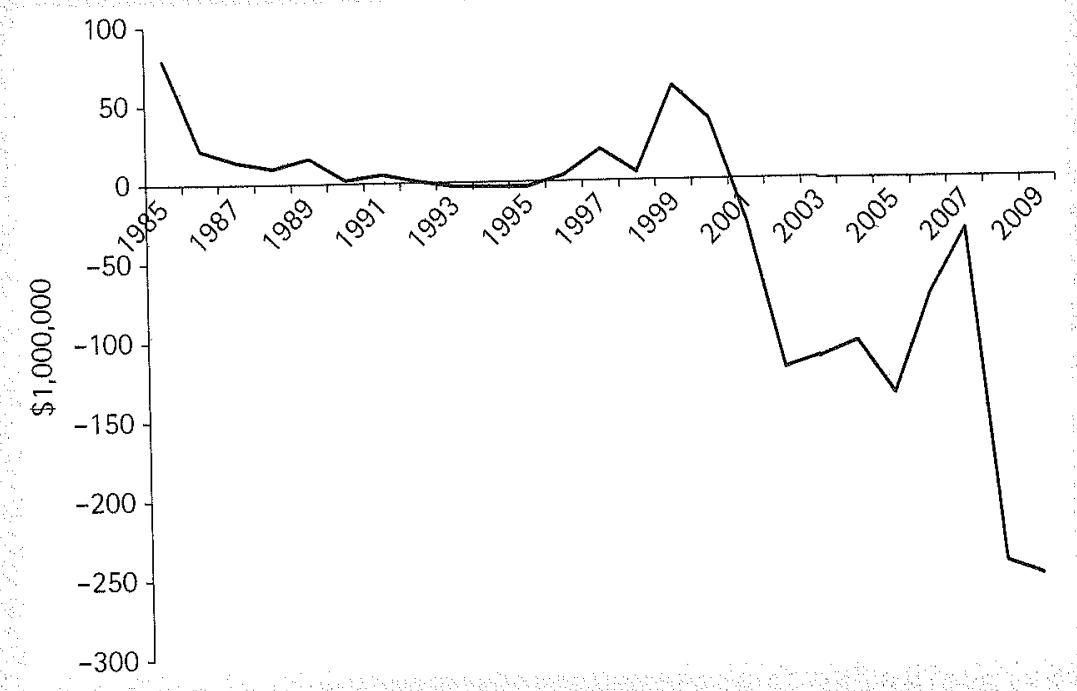

FIGURE 3.8 Net Funding Status of Pension Plans
1980 and 1990s, the net funding status of the average fund remained above zero, but then after 2001, it declined significantly and has deteriorated further during the latest recession.

A stock market boom could restore these funds to health, but failing that the cost of this underfunding will likely be transferred to taxpayers, as the Pension Benefit Guarantee Corporation bails out funds that cannot meet their obligation.

\section{CONCLUSION}

Under the tutelage of newly empowered institutional investors, executives pursued shareholder value with the tools of agency theory. They changed much about the way they did business. Firms used to pay the CEO 20 times what the average employee made. Now they pay the CEO a hundred times as much, draining value from investors. They used to pursue conglomeration to spread risk. Lately they have bought and sold units to focus on a single industry, and have laid off hordes in the process. They used to borrow 40 cents on the equity dollar, and now they borrow 60 cents, which increases the risk of bankruptcy and corporate raiding of the pension fund. Firms used to announce layoffs when their sales slowed. Now they lay off workers when sales are booming in the hope of boosting stock price. They used to put money in the pension fund for a rainy day. Now they let someone else worry about rainy days, with the result that each stock market drop puts funds further in the red.

These changes were promoted by proponents of the shareholder value revolution, in the name of reorienting the firm to the true interest of shareholders in the steady rise of firm value. The new business practices were outlined by agency theorists in economics in the 1970 and 1980 s, but institutional investors made them popular, often despite the resistance of corporate leaders who were mostly content with the status quo, in which their positions were stable and their firms were protected from the ups and downs of the market. Institutional investors did not find it easy to convince executives to dediversify, use debt financing, accept stock option compensation, or focus on cutting costs rather than expanding by conglomeration. But the end result of these changes has been a bonanza for the financial elite of fund managers, securities analysts, investment bankers, and corporate executives themselves.

The impact of these innovations on the average worker or pensioner who holds stock through a pension fund has generally been negative. While it is certainly the case that the one interest all shareholders, from the investment banker down to the assembly line worker, have in common is to see share value rise, the growing primacy of share value has not served the other interests of the average worker or pensioner, who is not only the most common shareholder but is increasingly, with her fellows, the majority shareholder in America's largest corporations. We have reviewed evidence that many innovations pursued under the banner of shareholder value produced results that conflicted sharply with the interests, and likely the values, of the average shareholder. 
If the shareholder value movement had unambiguously enriched the average investor in the process, then we might conclude that institutional investors who promoted agency theory precepts had served their masters, the shareholders, well. The agency theory prescriptions designed to make the firm more entrepreneurial and focused have changed how firms behave, but evidence does not suggest that firms that adopted them saw improvements in earnings or share value. The evidence points to the conclusion that institutional investors who championed agency theory have failed to promote shareholder value even in the narrow sense of increasing share price.

\section{REFERENCES}

Amihud, Y. and Lev, B. (1981). "Risk Reduction as a Managerial Motive for Conglomerate Mergers." Bell Journal of Economics, 12: 605-17.

(1998). The New Financial Capitalists: Kohlberg Kravis Roberts and the Creation of Corporate Value. Cambridge: Cambridge University Press.

(Fxecutive Compensation as an Agency Problem" Bebchuk, L. A. and Fried, T. M. (2003). "Executiv

D. I. (2002).

- and Walker, D. I. (2002). "Managerial Power and Rent Extraction in the

Executive Compensation." University of Chicago Law Review, 69/3: 751-846. Review, 120/12: 3-16.

Review, Bettis, R. A. (1983). "Modern Financial Theory, Corporate Strateg

Conundrum." Academy of Management Review, 8/3: 406-15. Bhagat, S., Shleifer, A., and Vishny, R. W. (1990). "Hostile Takeovers in the 1980s: The Return to Corporate Specialization," in C. Winston and M. N. Baily (eds.), Brooking Propers Press, Economic Activity: Microeconomics 1990. Washington, DC: Brookings Institution Press, $1-84$

Blair, M. M. (1995). Ownership and Control: Re-Thinking Corporate Governance for the TwentyFirst Century. Washington, DC: Brookings Institute.

(The New Capitalism and Organizational Rationality: The Adoption of Dow A. (1ing Programs, 1979-1994." Social Forces, 76/1: 229-49.

Downsizing Buessing, $M$, and Soto, $\mathrm{M}$.

for Retirement Kedia, S. (2006). "The Impact of Performance-Based Compensation on Misreporting." Journal of Financial Economics, 79/1: 35-67.

Media, S. (2002). "Explaining the Diversification Discount." Journal of Finance, 57/4: 1731-62.

Campello, M. (2003). "Capital Structure and Product Markets Interactions: Evidence from Business Cycles." Journal of Financial Economics, 68/3: 353-78.

" "Debt Financing: Does it Boost or Hurt Firm Performance in Product Markets?" Journal of Financial Economics, 82/1: 135-72.

(1998) "Amid Big Losses, Sunbeam Plans to Cut 6,400 Jobs and 8 Plants." The New York Times, May 12: D1.

Cappelli, P. (1999). The New Deal at Work: Managing the Market-Driven Workforce. Boston, MA: Harvard Business School Press.
Carleton, W. T, Nelson, J. M., and Weisbach, M. S. (1998). "The Influence of Institutions on Corporate Governance through Private Negotiations: Evidence from TIAA-CREF." Journal of Finance, 53/4: 1335-62.

Cauley, L. (1997). "Bell Atlantic, Nynex Job Cuts to Hit 10,000." The Wall Street Journal, May 6: $\mathrm{A} 3$.

Coffee, J. C., Jr. (1991). "Liquidity versus Control: The Institutional Investor as Corporate Monitor." Columbia Law Review, 91/6:1277-368.

Collins, G. (1996). "Sunbeam to Halve Work Force of 12,000 and Sell Some Units." The New York Times, November 13: D1.

Crutchley, C. E. and Hansen, R. S. (1989). "A Test of the Agency Theory of Managerial Ownership, Corporate Leverage, and Corporate Dividends." Financial Management, 18/4:36-46.

Dalton, D. R., Daily, C. M., Certo, S. T., and Roengpitya, R. (2003). "Meta-Analyses of Financial Performance and Equity: Fusion or Confusion?" Academy of Management Journal, 46/1: $13-26$.

Daris, G. F. and Kim, E. H. (2007). "Business Ties and Proxy Voting by Mutual Funds." Journal of Financial Economics, 85/2: 552-70.

- and Stout, S. K. (1992). "Organization Theory and the Market for Corporate Control: A Dynamic Analysis of the Characteristics of Large Takeover Targets, 1980-1990." Administrative Science Quarterly, 37/4: 605-33.

- Diekmann, K. A., and Tinsley, C. H. (1994). "The Decline and Fall of the Conglamerate Firm in the 1980s: The Deinstitutionalization of an Organizational Form." American Sociological Review, 59/4: 547-70.

Degeorge, F., Patel, J., and Zeckhauser, R. (1999). “Earnings Management to Exceed Thresholds." Journal of Business, 72/1: 1-33.

DeNaras-Walt C Proctor, B, D, and Smith, I. C. (2010). "Income, Poverty, and Health Insurance Coverage in the United States: 2009." Current Population Reports, 60-238.

Dobbin, F. (1992). "The Origins of Private Social Insurance: Public Policy and Fringe Benefits in America, 1920-1950." American Journal of Sociology, 97/5: 1416-50.

- and Zorn, D. M. (2005). "Corporate Malfeasance and the Myth of Shareholder Value." Political Power and Social Theory, 17: 179-98.

Donaldson, T and Preston, L. E. (1995). "The Stakeholder Theory of the Corporation: Concepts, Evidence, and Implications." Academy of Management Review, 20/1: 65-91.

Efendi, J., Srivastava, A., and Swanson, E. P. (2007). "Why Do Corporate Managers Misstate Financial Statements? The Role of Option Compensation and Other Factors." Journal of Financial Economics, 85/3: 667-708.

Eisenhardt, K. M. (1989). "Agency Theory: An Assessment and Review," Academy of Management Review, 14/1: 57-74.

Fama, E. F. (1980). "Agency Problems and the Theory of the Firm." Journal of Political Economy, 88/2: 288-307.

and Jensen, M. C. (1983). "Separation of Ownership and Control." Journal of Law and Economics, 26/2: 301-25.

_ (1985). "Organizational Forms and Investment Decisions." Journal of Financial Economics, 14/1: 101-19.

Finnerty, J.D. (1985). "Stock-for-Debt Swaps and Shareholder Returns." Financial Management, $14 / 3: 5-17$

Fligstein, N. and Markowitz, L. (1993). "Financial Reorganization of American Corporations in the 1980s," in W. J. Wilson (ed.), Sociology and the Public Agenda. Beverly Hills, CA: Sage Publications, $185-206$. 
Flynn, L. J. (2006). "Sun Says It Will Cut at Least 4,000 Jobs." The New York Times, May 31: C1. Freeman, R. E. (1984). Strategic Management: A Stakeholder Approach. Boston, MA: Pitman.

Gilpin, K. N. (1995). “Lockheed to Eliminate 12,000 Jobs." The New York Times, June 27: D1. Gourevitch, P. A. and Shinn, J. (2005). Political Power and Corporate Control: The New Global Politics of Corporate Governance. Princeton, NJ: Princeton University Press.

Hacker, J. S. (2006). The Great Risk Shift: The Assault on American Jobs, Families, Health Care, and Retirement and How You Can Fight Back. Oxford: Oxford University Press.

Hall, B. J. and Liebman, J. B. (1998). "Are CEOS Really Paid Like Bureaucrats?" Quarterly Journal of Economics, 113/3: 653-91.

Hamdallah, A. E.-S. and Ruland, W. (1986). "The Decision to Terminate Overfunded Pension Plans." Journal of Accounting and Public Policy, 5/2: 77-91.

Hammer, M. and Champy, J. (1993). Reengineering the Corporation: A Manifesto for Business Revolution. New York: Harper Business.

Harrison, B. and Bluestone, B. (1988). The Great U-Turn: Corporate Restructuring and the Polarizing of America. New York: Basic Books.

Holmstrom, B. and Kaplan, S. N. (2001). "Corporate Governance and Merger Activity in the United States: Making Sense of the 1980s and 1990s." Journal of Economic Perspectives, 15: $121-44$.

Holusha, J. (1993a). “10,000 Jobs to Be Cut by Kodak.” The New York Times, December 9: D1. (1993b). "A Profitable Xerox Plans to Cut Staff by 10,000." The New York Times, August 19: D1.

Ippolito, R. A. and James, W. H. (1992). "LBOs, Reversions and Implicit Contracts." Journal of Finance, 47/1: 139-67.

Jacoby, S. M. (2007). "Principles and Agents: CalPERS and Corporate Governance in Japan." Corporate Governance, 15/1: 5-15.

Jensen, M. C. (1984). “Takeovers: Folklore and Science." Harvard Business Review, 62/6 $109-21$.

(1986). "Agency Costs of Free Cash Flow, Corporate Finance, and Takeovers." American Economic Review, 76/2: 323-9.

- (1989). "Eclipse of the Public Corporation." Harvard Business Review, 67/5: 61-74.

- and Meckling, W. H. (1976): "Theory of the Firm: Managerial Behavior, Agency Costs, and Ownership Structure." Journal of Financial Economics, 3/4: 305-60.

Jensen, M. C. and Murphy, K. J. (1990). "Performance Pay and Top-Management Incentives." Journal of Political Economy, 98/2: 225-264.

Johnson, S. (2008). "Faltering Economic Growth and the Need for Economic Stimulus". Hearing of the Joint Economic Committee of Congress, October 30.

Khurana, R. (2002). Searching for a Corporate Savior: The Irrational Quest for Charismatic CEOs. Princeton, NJ: Princeton University Press.

Lazonick, W. and O'Sullivan, M. (2000). "Maximizing Shareholder Value: A New Ideology for Corporate Governance." Economy and Society, 29/1: 13-35.

LeBaron, D. and Speidell, L. S. (1987). "Why Are the Parts Worth More than the Sum? 'Chop Shop; a Corporate Valuation Model," in L. E. Browne and E. S. Rosengren (eds.), The Merger Boom. Boston, MA: Federal Reserve Bank of Boston, 78-101.

Liebeskind, J. P., Opler, T. C., and Hatfield, D. E. (1996). "Corporate Restructuring and the Consolidation of US Industry." Journal of Industrial Economics, 44/1:53-68.

Lys, T. and Sivaramakrishnan, K. (1988). "Earnings Expectations and Capital Restructuring: The Case of Equity-for-Debt Swaps," Journal of Accounting Research, 26/2: 273-99.
Matsusaka, J. G. (1993). "Takeover Motives during the Conglomerate Merger Wave." RAND Journal of Economics, 24/3: 357-79.

Mittelstaedt, H. F. (1989). "An Empirical Analysis of the Factors Underlying the Decision to Remove Excess Assets from Overfunded Pension Plans." Journal of Accounting and Economics, 11/4: 399-418.

Modigliani, F. and Merton, H. M. (1958). "The Cost of Capital, Corporation Finance and the Theory of Investment." American Economic Review, 48/3:261-97.

Morris, M. A. and Western, B. (1999). "Inequality in Earnings at the Close of the Twentieth Century." Annual Review of Sociology, 25/1: 623-57.

Munnell, A. H. and Soto, M. (2007). "Why Are Companies Freezing Their Pensions?" Working paper. <http://papers.ssrn.com/sol3/papers.cfm?abstract_id=1545916> (accessed August 3, 2011).

- Golub-Sass, F., Soto, M., and Vitagliano, F. (2006). "Why Are Healthy Employers Freezing Their Pensions?" Center for Retirement Research at Boston College, Issue in Brief no. 44 .

Osterman, P. (1999). Securing Prosperity. Princeton, NJ: Princeton University Press.

Parrino, R., Sias, R. W., and Starks, L. T. (2003). "Voting with Their Feet: Institutional Ownership Changes around Forced CEO Turnover." Journal of Financial Economics, 68/1: $3-46$

Peters, T. J. and Waterman, R. H. (1982). In Search of Excellence: Lessons from America's BestRun Companies. New York: Harper \& Row.

Piketty, T. and E. Saez. (2003). "Income Inequality in the United States: 1913-1998." Quarterly Journal of Economics, 118/1: 1-39.

- (2009). "Income Inequality in the United States: Updated Tables." <http://elsa.berkeley. edu/ saez/TabFig2007.xls> (accessed August 3, 2011).

Posner, R. A. (2009). A Failure of Capitalism: The Crisis of 'o8 and the Descent into Depression. Cambridge, MA: Harvard University Press.

Prahalad, C. K. and Hamel, G. (1990). "The Core Competence of the Corporation." Harvard Business Review, 68/3: 79-91.

Proffitt, W. T. (2001). "The Evolution of Institutional Investor Identity: Social Movement Mobilization in the Shareholder Activism Field." PhD thesis, Northwestern University, Evanston, IL.

Romero, S. (2000). "Qwest Stock Dips on News of 13,000 Layoffs." The New York Times, September 8: C6.

Sanders, W. G. and Hambrick, D. C. (2007). "Swinging for the Fences: The Effects of CEO Stock Options on Company Risk Taking and Performance." Academy of Management Journal, 50/5: 1055-78

Schwab, S. J. and Thomas, R. S. (1998). "Realigning Corporate Governance: Shareholder Activism by Labor Unions." Michigan Law Review, 96/4: 1018-94.

Servaes, H. (1996). "The Value of Diversification During the Conglomerate Merger Wave." Journal of Finance, 51/4: 1201-25.

Shleifer, A. and Summers, L. H. (1988). "Breach of Trust in Hostile Takeovers", in A. J. Auerbach (ed.), Corporate Takeovers: Causes and Consequences. Chicago: University of Chicago Press, $33-67$.

— and Vishny, R. W. (1989). "Management Entrenchment: The Case of Manager-Specific Investments." Journal of Financial Economics, 25/1: 123-39.

_- (1997). "A Survey of Corporate Governance." Journal of Finance, 52/2: 737-83. 
Sims, C. (1993). "Martin Marietta to Eliminate 11,000 Jobs." The New York Times, October 1: D1.

Sorkin, A. R. (2009). Too Big to Fail: The Insider Story of How Wall Street and Washington Fought to Save the Financial System from Crisis-and Themselves. New York: Viking.

The Transition from Capitalism to Socialism. London: Macmillan.

Stephen Pension Plan Terminations." Stone, M. (1987). A Financing Explanation for

Teece D. J (1982) "Towards an Economic Theory of the Multiproduct Firm." Journal of Economic Behavior e' Organization, 3/1: 39-63.

Thelen, K. (2003). "How Institutions Evolve: Insights from Comparative Historical Analysis," in Iahoney and D. Rueschemeyer (eds.), Comparative Historical Analysis in the Social Sciences. Cambridge: Cambridge University Press, 208-69.

Sciences. Cambridge: Cambridge University Press, 208-69. Corporate America. New York: Basic Books.

Corporate Americis . "Does Diversification Cause the 'Diversification Discount'?" Financial Management, 33/2: 5-27.

Walther, T. (1997). Reinventing the CFO: Moving from Financial Management to Strategic Management. New York: McGraw-Hill.

Wernerfelt, B. and Montgomery, C. A. (1988). "Tobin's $q$ and the Importance of Focus in Firm Performance." American Economic Review, 78/1: 246-50.

(1998). "The Symbolic Management of Stockholders: Corporate (a) $127-53$

"SBC-AT\&T Deal Relies on Savings Through Job Cuts." The Wall Street Journal, February 2: A2.

E J J and Westphal, J. D. (2004). "The Social Construction of Market Value: Instion Market Reactions." American Sociological Review, 69/3: 433-57.

Zuckerman, E. W. (1999). "The Categorical Imperative: Securities Analysts and the Illegitimacy Discount." American Journal of Sociology, 104/5: 1398-438.

Discone "Focusing the Corporate Product: Securities Analysts and De-diversification." Administrative Science Quarterly, 45/3: 591-619.
CHAPTER 4

BUSINESS GROUPS AND

FINANCIAL MARKETS AS

EMERGENT PHENOMENA ${ }^{1,2}$

THE study of the business group was once lamented for its paucity of research. The research of the past two decades has remedied this deficit quantitatively and qualitatively. However, the search for robust findings has proved often elusive, a challenge for comparative economic sociology in general due to the complexity of the subject and the uneven access to data. This chapter proposes an alternative perspective on business groups, and their relation to finance, to respond to this challenge.

This perspective draws upon the sciences of complexity. The sociology of financial markets can be viewed as a search to link the emergence of the macrostructural patterns in economic markets to the micro-behaviors of participants, or agents, in these markets. The clues to this investigation are the signatures in these patterns that are known to be expressions of particular types of generating rules that guide the actions of these agents. While these signatures are statistical, their origins and dynamics are governed by the social relations among traders, investors, and entrepreneurs. Financial and economic markets are complex systems, and yet considerable progress has been made toward understanding their structural patterns and dynamics, and the micro-behaviors of traders and the rules by which they interact.

Business groups are sociologically important because they are invariably associated with economic and political power through their control over sizeable business enterprises. They pose the interesting question of why this form is so pervasive across countries despite large institutional differences. Their common occurrence across many countries suggests that they are emergent phenomena arising from similar underlying dynamics. While pervasive, they come in many varieties and flavors. Therefore, a simple definition is valuable. Granovetter (2005) offers such a definition in the following "'Business groups' are sets of legally separate firms bound together in persistent formal and/or informal ways." 